University of Nebraska - Lincoln

DigitalCommons@University of Nebraska - Lincoln

Comparative gene mapping: cytogenetic localization of PROC, EN1, ALPI, TNP1, and IL1B in cattle and sheep reveals a conserved rearrangement relative to the human genome

\author{
N. L. Lòpez-Corrales \\ Roslin Institute (Edinburgh), Roslin, Midlothian, Edinburgh \\ T. S. Sonstegard \\ USDA/ARS Beltsville Agricultural Research Center, Beltsville, MD \\ T. P. L. Smith \\ U.S. Meat Animal Research Center, tim.smith@usda.gov
}

Follow this and additional works at: https://digitalcommons.unl.edu/hruskareports

Part of the Animal Sciences Commons

Lòpez-Corrales, N. L.; Sonstegard, T. S.; and Smith, T. P. L., "Comparative gene mapping: cytogenetic localization of PROC, EN1, ALPI, TNP1, and IL1B in cattle and sheep reveals a conserved rearrangement relative to the human genome" (1998). Roman L. Hruska U.S. Meat Animal Research Center. 173.

https://digitalcommons.unl.edu/hruskareports/173

This Article is brought to you for free and open access by the U.S. Department of Agriculture: Agricultural Research Service, Lincoln, Nebraska at DigitalCommons@University of Nebraska - Lincoln. It has been accepted for inclusion in Roman L. Hruska U.S. Meat Animal Research Center by an authorized administrator of DigitalCommons@University of Nebraska - Lincoln. 


\title{
Comparative gene mapping: cytogenetic localization of PROC, EN1, ALPI, TNP1, and IL1B in cattle and sheep reveals a conserved rearrangement relative to the human genome
}

\author{
N.L. Lòpez-Corrales, ${ }^{a}$ T.S. Sonstegard, ${ }^{b}$ and T.P.L. Smith ${ }^{c}$ \\ a Roslin Institute (Edinburgh), Roslin, Midlothian, Edinburgh (UK); \\ ${ }^{b}$ USDA/ARS Beltsville Agricultural Research Center, Beltsville, MD (USA); and \\ c USDA/ARS Roman L. Hruska US Meat Animal Research Center, Clay Center, NE (USA)
}

\begin{abstract}
The cytogenetic locations of the genes for protein C (PROC), transition protein 1 (TNP1), intestinal alkaline phosphatase (ALPI), engrailed (EN1), and human protointerleukin $\beta$ (IL1B) have been compared between cattle (Bos taurus, BTA) and sheep (Ovis aries, OAR). Bovine YAC and cosmid clones were used as FISH probes to determine the order (centromere to telomere) of four of these genes on OAR 2q, as
\end{abstract}

well as the location of IL1B on OAR 3p. In cattle, IL1B and EN1 were assigned to BTA 11 and BTA 2, respectively. Alignment of the ovine, bovine, and human physical maps based on these data shows that segments of conserved synteny and chromosomal rearrangements detected between cattle and human are also found in sheep, where the order in cattle is conserved.
Comparative mapping allows the use of gene mapping information gathered in one species to be applied to all species for which the framework of conserved genome organization is known (Andersson et al., 1996). An overview of segments of conserved synteny that exist between distantly related mammalian species can be revealed by ZOO-FISH methodology (Hayes et al., 1995; Rettenberger et al., 1995; Solinas-Toldo et al., 1995; Chowdary et al., 1996; Radusepp et al., 1996). The comparative approach is especially important for developing gene maps in livestock. The success of this type of analysis is dependent on the development of comparative maps between humans, mice, and livestock species that identify breakpoints in the conservation of synteny and changes in gene order within the conserved syntenic groups.

Comparative mapping of the bovine homologs of genes found on human chromosome 2q (Fisher et al., 1997; Smith et

\footnotetext{
Received 10 July 1998; revision accepted 4 September 1998.

Request reprints from Dr. Timothy P.L. Smith, USDA/ARS Roman L. Hruska US Meat Animal Research Center, PO Box 166, Clay Center, NE 68933 (USA); telephone: 402-762-4366; fax: 402-762-4390;

e-mail: smith@email.marc.usda.gov.
}

al., 1997; Sonstegard et al., 1997) has defined a segment of conserved synteny between the human (Homo sapiens, HSA) and cattle (Bos taurus, BTA) chromosomes 2. These comparisons have been useful in predicting the location of the "double-muscling" locus (mh) (Smith et al., 1997). ZOO-FISH and linkage data (Hayes, 1995; Solinas-Toldo et al., 1995; Chowdary et al., 1996; Fisher et al., 1997; Sonstegard et al., 1997) indicates that most of BTA $2 \mathrm{q} 12 \rightarrow \mathrm{q} 42$ corresponds to HSA 2q. Within this conserved synteny, a rearrangement of gene order between BTA 2 q12 $\rightarrow$ q44 and HSA 2 q14 $\rightarrow$ q37 was detected by positioning the COL3A1 gene (HSA 2q31 $\rightarrow \mathrm{q} 32.3$ ) in the pericentromeric region of BTA 2 (Fisher et al., 1997; Sonstegard et al., 1997) and linkage data placing interleukin-1 receptor $\alpha$ (IL1RA, located at HSA 2q12) on BTA 11 (Yoo, et al 1994), indicated that two specific rearrangements occurred on HSA 2q with respect to BTA 2 . In contrast, one segment containing the genes for glucagon (GCG) and nebulin (NEB) shows a larger region of gene order conservation of four human genes on BTA 2 (Sonstegard et al., 1997; Smith, 1997), which has also been reported in goat and sheep (Lòpez-Corrales et al., 1997).

The objective of this study was to apply a comparative mapping strategy to more narrowly refine the position of evolutionary chromosomal rearrangements and determine if the rear-

\begin{tabular}{lll}
\hline KARGER & $\begin{array}{l}\text { E-mail karger@karger.ch } \\
\text { Fax +41 61306 12 34 } \\
\text { http://www. karger.com }\end{array}$ & (c) 1997 S. Karger AG, Basel \\
$0301-0171 / 98 / 0832-0035 \$ 17.50 / 0$
\end{tabular}



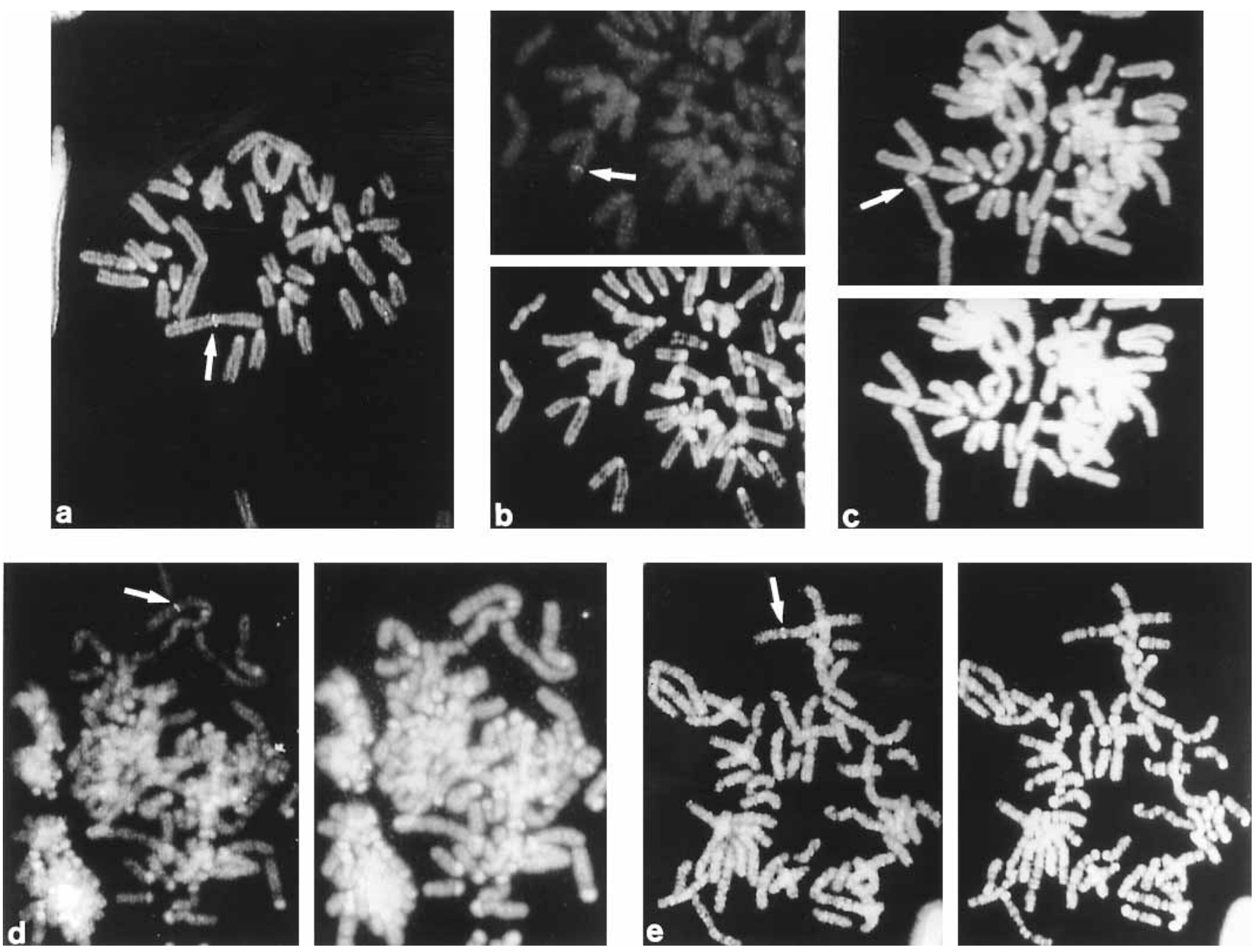

Fig. 1. FISH analysis of five probes in sheep: (a) PROC (OAR 2q12); (b) TNP1 (OAR 2q33 $\rightarrow$ q34); (c) ALPI (OAR 2q35); (d) EN1 (OAR 2q28 $\rightarrow$ q210); (e) IL1B (OAR 3p26 $\rightarrow$ p25).

gements and breakages in the conserved synteny observed between HSA 2 q and BTA 2 have also been conserved in sheep (Ovis aries, OAR). We used five probes of bovine type I loci (PROC, TNP1, ALPI, IL1B, and EN1) to detect these rearrangements in sheep. Three probes (PROC, TNP1, and ALPI) were previously assigned in human and cattle by FISH (Sonstegard et al., 1997). The data should provide two new physical assignments of Type I loci to the cattle map (IL1B and EN1) and extend the physical map coverage in sheep with five new cytogenetic assignments, including TNP1, which was previously localized to OAR 2 (Pitel et al., 1994).

\section{Materials and methods}

Isolation and analysis of genomic probes for FISH

Sequences of the human versions of EN1 and IL1B were obtained from GenBank and used to design primer pairs that amplified exons of EN1 and IL1B. Cosmid clones for these two genes were isolated from a bovine cosmid library in pWE15 (Stratagene), and the DNA was isolated by using ionic exchange columns according to the manufacturer's (Qiagen) protocol. The presence of the target genes in the cosmid clones was detected by sequence analysis and PCR with other exon-specific primers. The isolation and characterization of YAC and cosmid probes for TNP1, PROC, and ALPI have been described elsewhere (Smith et al., 1997; Sonstegard et al., 1997). Bovine YAC DNA was obtained as total yeast DNA preparations with DNAzol (MRC) from $50 \mathrm{mg}$ of yeast cells according to the manufacturer's protocol.

\section{Chromosome preparation and FISH analysis}

Cosmids and YAC probes were labeled with biotin by nick translation using a BioNick kit (GIBCO) and purified on commercial Sephadex columns (5prime-3prime). FISH analysis was performed according to the original method of Lichter et al. (1990) and Ponce de Leòn et al. (1996). Chromosome spreads were obtained from peripheral whole blood cell cultures, and Rbanding of metaphase preparations was carried out according to Lemieux et al. (1992).

Digital imaging and probe localization

Digital images were obtained using a Zeiss Axioscope epifluorescence microscope coupled to a cooled CCD camera. Fluorescein isothiocyanate (FITC) and propidium iodide (PI) signals were detected with a BP450-490 

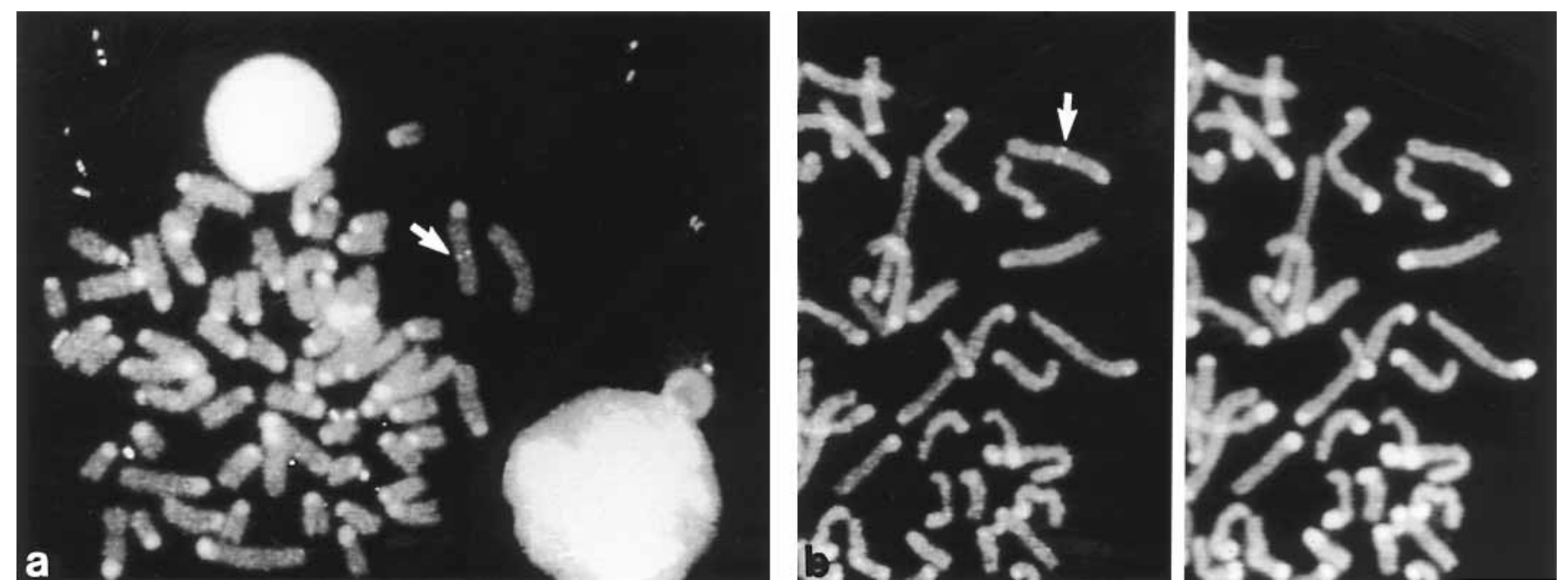

Fig. 2. Cytogenetic localization of EN1 and IL1B in cattle: (a) EN1 (BTA 2q32 $\rightarrow$ q33); (b) IL1B (BTA 11q22.1 $\rightarrow$ q22.3).

Table 1. Cytogenetic localization of five loci in sheep and cattle

\begin{tabular}{lll}
\hline Locus & Sheep & Cattle \\
\hline PROC & OAR 2q12 & \\
EN1 & OAR 2q28 $\rightarrow \mathrm{q} 210$ & BTA 2q32 $\rightarrow \mathrm{q} 33$ \\
TNP1 & OAR 2q33 $\rightarrow \mathrm{q} 34$ & \\
ALPI & OAR 2q35 & \\
IL1B & OAR 3p26 $\rightarrow \mathrm{p} 25$ & BTA 11 $122.1 \rightarrow \mathrm{q} 22.3$ \\
\hline
\end{tabular}

filter (Zeiss), recorded, and photographed from the display monitor. Hybridization signals were assigned to specific bands according to the standard nomenclatures for R-banded sheep and cattle chromosomes (Di Berardino and Iannuzzi, 1989; ISCNDA 1989, Iannuzzi et al., 1995a, b).

\section{Results}

Probes for FISH analysis were chosen on the basis of loci which were known or predicted to reveal chromosomal rearrangements between cattle and humans. In sheep, IL1B was shown to hybridize to OAR $3 \mathrm{p} 26 \rightarrow \mathrm{p} 25$. The assignments for PROC, TNP1, EN1, and ALPI were observed on OAR 2q12, 2q33 $\rightarrow$ $\mathrm{q} 34,2 \mathrm{q} 28 \rightarrow \mathrm{q} 210$, and $2 \mathrm{q} 35$, respectively (Table 1). These genes should maintain the same order and centromere-telomere orientation in sheep, cattle, and human. Furthermore, the location of EN1 and IL1B in sheep at OAR 2 q28 $\rightarrow$ q210 and OAR 3 p26 $\rightarrow$ p 25 (Fig. 1), respectively, and in cattle at BTA $2 \mathrm{q} 32 \rightarrow \mathrm{q} 33$ and BTA $11 \mathrm{q} 22.1 \rightarrow \mathrm{q} 22.3$ (Fig. 2), respectively, show that breakage in the conserved synteny between cattle and humans is conserved in sheep (Fig. 3). The breakpoint lies in the narrow interval between IL1B and EN1, as defined by positioning of these loci on the transcript human map (http:/ /www.ncbi.nlm.nih. gov/cgibin/SCIENCE96/chr?2). a)
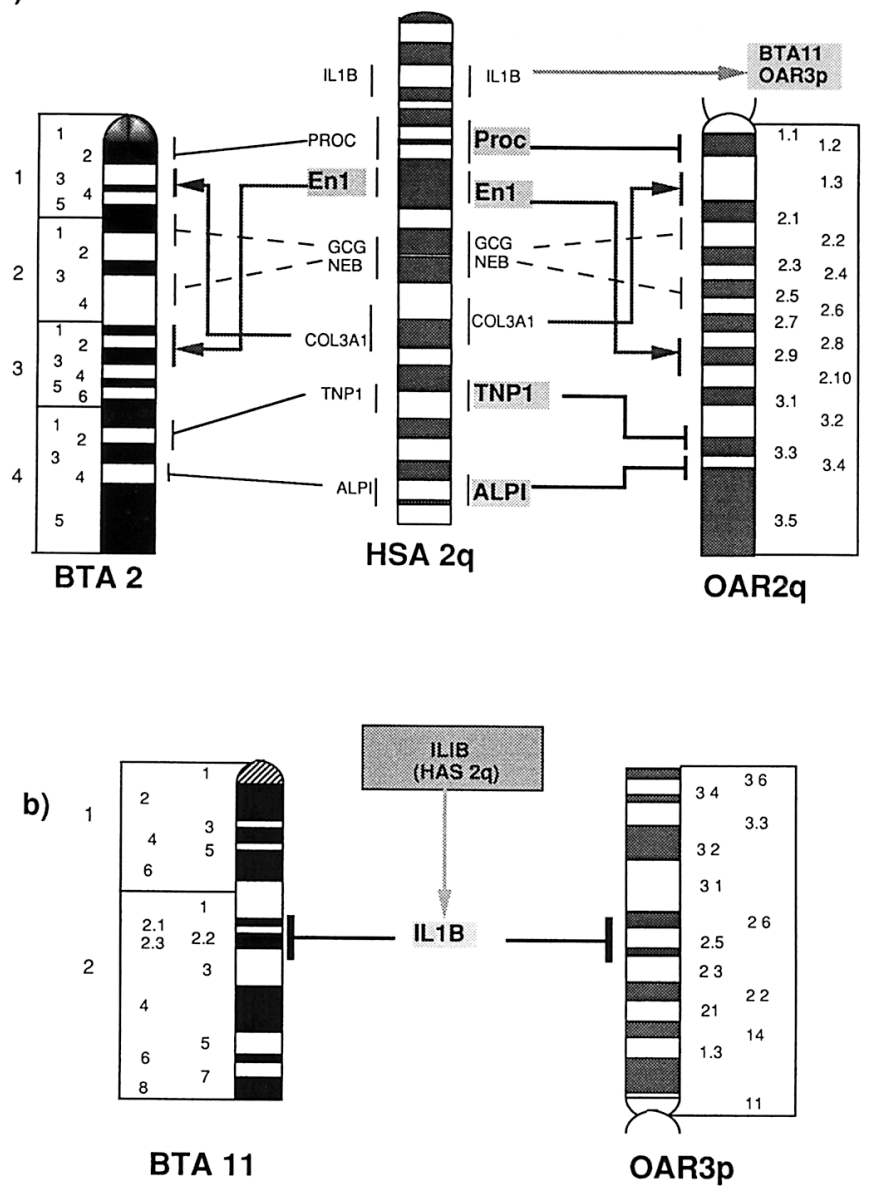

Fig. 3. Comparison of the physical maps of BTA 2, OAR 2q, and HSA 2q: (a) PROC (OAR 2q12), EN1 (OAR 2q28 $\rightarrow$ q210 and BTA 2q32 $\rightarrow$ q33), TNP1 (OAR 2q33 $\rightarrow \mathrm{q} 34$ ), and ALPI (OAR 2q35); (b) IL1B (BTA $11 \mathrm{q} 22.1 \rightarrow \mathrm{q} 22.3$ and OAR 3p26 $\rightarrow$ p25). Loci assigned by FISH in this work are indicated in boldface type. Rearrangements involving the physical locations of EN1 and COL3A1 are indicated. 


\section{Discussion}

Marked conservation of synteny between HSA 2q, mouse (Mus musculus) chromosome 2 (MMU 2), and BTA 2 was reported by Pitel et al. (1994). Comparison of HSA 2q and BTA 2 showed that PROC, TNP1, and ALPI maintain the same chromosomal centromere-telomere orientation but are not maintained within a single segment of conserved synteny (Sonstegard et al., 1997). Additionally, Lòpez-Corrales et al. (1997) determined that the relative physical locations of GCG and NEB are conserved on HSA 2q, BTA 2, OAR 2q, and goat chromosome 2.

In this study, the assignments of EN1 and IL1B support the previous work by refining the breakpoints in the apparently large segment of conserved synteny between humans and bovids. One of the disruptions in gene order conservation appears to be located within a portion of the genome corresponding to HSA 2q22. Likewise, in cattle and sheep the loci order is PROC-GCG-NEB-EN1-TNP1-ALPI, as compared to PROC-EN1-GCG-NEB-TNP1-ALPI on HSA 2q. These results demonstrate that chromosomal homology between mammals on a gross scale is not always indicative of conserva- tion of gene order. The presence of interruptions in conserved synteny and gene order rearrangements underscore the need to develop dense comparative maps using genetic linkage data, physical assignments, and/or radiation hybrid maps.

The conservation of synteny between HSA 2q, MMU 2, and BTA 2 (Pitel et al., 1994) is also found in sheep. This physical mapping observation supports the results of previous comparative physical (INHBB: Goldammer et al., 1995; COL3A1: Broad et al., 1995; Sonstegard et al., 1997; GCG and NEB: Lòpez-Corrales et al., 1997) and linkage mapping studies (De Gortari et al., 1998) which suggested a relatively high degree of conservation of loci order between sheep and cattle, especially between BTA 2 and OAR 2. Our findings also show that the breakpoint defined by the location of IL1B on BTA 11 is conserved in sheep with the assignment of this locus to OAR $3 p$. Although no differences in gene order or synteny were found between BTA 2 and OAR 2q, subchromosomal changes between related species do exist (Iannuzzi et al., 1995a, b; Ponce De Leòn et al., 1996). A more refined comparative map between closely related karyotypes should clarify the relationship between chromosomal banding homology and conserved synteny.

\section{References}

Andersson L: Comparative Genome Organization: First International Workshop. Mammal Genome 7:7171-7734 (1996).

Broad TE, Lewis PE, Burkin DJ, Gleeson AJ, Carpenter MA, Jones C, Pearce PD, Maher DW, Ansari HA: Thirteen loci physically assigned to sheep chromosome 2 by cell hybrid analysis and in situ hybridisation. Mammal Genome 6:862-866 (1995).

Chowdhary BP, Fronicke L, Gustavsson I, Scherthan $\mathrm{H}$ : Comparative analysis of the cattle and human genomes: detection of ZOO-FISH and gene mapping-based chromosomal homologies. Mammal Genome 7:297-302 (1996).

De Gortari M, Freking B, Cuthbertson RP, Kappes SM, Keele JW, Stone RT, Leymaster KA, Dodds KG, Crawford AM, Beattie CW: A second-generation linkage map of the sheep genome. Mammal Genome 9:204-209 (1998).

Di Berardino D, Iannuzzi L: Detailed description of Rbanded bovine chromosomes. J Hered 73:434-438 (1989).

Fisher SR, Beever JE, Lewing HA: Genetic mapping of COL3A1 to bovine chromosome 2. Mammal Genome 8:76-77 (1997).

Goldammer T, Brunner RM; Hiendleder S, Schewrin M: Comparative mapping of sheep inhibin subunit $\mathrm{Bb}$ to chromosome 2 in sheep and cattle by fluorescence in situ hybridization. Anim Genet 26:199200 (1995).

Hayes H: Chromosome painting with human chromosome-specific DNA libraries reveals the extent and distribution of conserved segments in bovine chromosomes. Cytogenet Cell Genet 71:168-174 (1995).
Hayes H, Petit E, Dutrillaux B: Comparison of RBGbanded karyotypes of cattle, sheep and goats. Cytogenet Cell Genet 57:51-55 (1991).

Heaton MP, Lòpez-Corrales NL, Smith TPL, Kappes SM, Beattie CW: Directed cosmid isolation of bovine marker for physical assignment by FISH. Anim Biotech 8:167-177 (1997).

Iannuzzi L, Di Meo GP, Perucatti A, Ferrara L: G- and R-banding comparison of sheep (Ovis aries L.) chromosomes. Cytogenet Cell Genet 68:85-90 (1995a).

Iannuzzi L, Pia Di Meo G: Chromosomal evolution in bovids: a comparison of cattle, sheep and goat Gand R-banded chromosomes and cytogenetic divergences among cattle, goat and river buffalo sex chromosomes. Chrom Res 3:291-299 (1995b).

ISCNDA 1989: International System for Cytogenetic Nomenclature of Domestic Animals, 1989. Cytogenet Cell Genet 53:65-79 (1990).

Lemieux N, Dutrillaux B, Viegas-Péquignot E: A simple method for simultaneous R- or G- banding and fluorescence in situ hybridization of small singlecopy genes. Cytogenet Cell Genet 59:311-312 (1992).

Lichter P, Tang CC, Call K, Hermanson G, Evans GA, Housman D, Ward DC: High resolution mapping of human chromosome 11 by in situ hybridization with cosmid clones. Science 237:64-69 (1990).

Lòpez-Corrales NL, Sonstegard TS, Smith TPL, Beattie $\mathrm{CW}$ : Physical assignment of glucagon and nebulin in cattle, sheep and goat. Mammal Genome 8:428429 (1997).
Pitel F, Lantier I, Tabet-Aoul K, Saidi-Mehtar N, Elsen J-M, Lantier F, Gellin J: TNP1: a sheep polymorphic marker for a conserved region among mammals. Mammal Genome 5:390-392 (1994).

Ponce de Leòn FA, Ambady A, Hawkins GA, Kappes SM, Bishop MD, Robl JM, Beattie CW: Development of a bovine $\mathrm{W}$ chromosome linkage group and painting probes to assess cattle, sheep and goat $\mathrm{X}$ chromosome segment homologies. Proc natl Acad Sci, USA 93:3450-3454 (1996).

Radusepp T, Fronicke L, Scherthan H, Gustavsson I, Chowdhary B: ZOO-FISH delineates conserved chromosomal segments in horse and man. Chrom Res 4:218-225 (1996).

Rettenberger G, Kunz J, Vogel W, Hameister H: Visualization of the conservation of synteny between humans and pigs by heterologous chromosomal painting. Genomics 26:372-378 (1995).

Smith TPL; Lòpez-Corrales NL, Kappes SM, Sonstegard TS: Myostatin maps the interval containing the bovine mh locus. Mammal Genome 8:742-744 (1997).

Solinas-Toldo S, Lengauer C, Fries R: Comparative genome map of human and cattle. Genomics 27:489-496 (1995).

Sonstegard TS, Lòpez-Corrales NL, Kappes SM, Beattie CW, Smith TPL: Comparative mapping of bovine and human chromosome 2 identifies segments of conserved synteny containing the bovine mh locus. Mammal Genome 8:750-754 (1997).

Yoo J, Stone RT, Kappes SM, Beattie CW: Linkage analysis of bovine interleukin receptor types I and II (IL-1RI, II). Mammal Genome 5:820-821 (1994). 